\title{
REVIEW \\ International Spinal Cord Injury Upper Extremity Basic Data Set
}

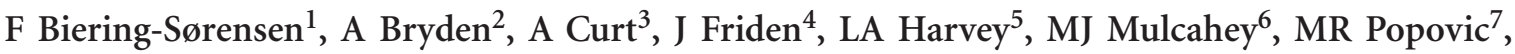 \\ A Prochazka ${ }^{8}$, KA Sinnott ${ }^{9}$ and G Snoek ${ }^{10}$
}

Objective: To develop an International Spinal Cord Injury (SCI) Upper Extremity Basic Data Set as part of the International SCI Data Sets, which facilitates consistent collection and reporting of basic upper extremity findings in the SCI population.

Setting: International.

Methods: A first draft of a SCI Upper Extremity Data Set was developed by an international working group. This was reviewed by many different organisations, societies and individuals over several months. A final version was created.

Variables: The final version of the International SCl Upper Extremity Data Set contains variables related to basic hand-upper extremity function, use of assistive devices, SCl-related complications to upper extremity function and upper extremity/hand reconstructive surgery. Instructions for data collection and the data collection form are freely available on the ISCoS website (www.iscos.org.uk).

Conclusion: The International SCI Upper Extremity Basic Data Set will facilitate consistent collection and reporting of basic upper extremity findings in the $\mathrm{SCl}$ population.

Spinal Cord (2014) 52, 652-657; doi:10.1038/sc.2014.87; published online 3 June 2014

\section{INTRODUCTION}

There is currently no consensus on the most appropriate data to collect about the upper extremity function of individuals with spinal cord injury (SCI). Yet it is important to have standardised data collection around the world, because this allows for comparisons of outcomes and helps facilitate SCI research. Therefore, a consensus panel was created, under the auspices of the International Spinal Cord Society (ISCoS) and the American Spinal Injury Association (ASIA), to develop a Basic Data Set for the Upper Extremity called the International Spinal Cord Injury (SCI) Upper Extremity Basic Data Set.

The purpose of the International SCI Upper Extremity Basic Data Set was to standardise the collection and reporting of a minimal amount of information about upper extremity status in accordance with the general purpose and vision of the International SCI Data Sets. ${ }^{1}$

The International SCI Upper Extremity Basic Data Set is to be used in connection with the International SCI Core Data Set, ${ }^{2}$ the International SCI Musculoskeletal Basic Data $\mathrm{Set}^{3}$ and the International SCI Pain Basic Data Set. ${ }^{4,5}$ The International SCI Core Data Set includes information on dates of birth and injury, gender, aetiology of spinal cord lesion and neurological status. It also captures information about the presence of vertebral injury, past surgical interventions, associated injuries, discharge destination and the need for mechanical ventilation. The International SCI Upper Extremity Basic Data Set is also to be used alongside the International Standards for the Neurological Classification of SCI (ISNCSCI) ${ }^{6}$ as well as the Spinal Cord Independence Measure. ${ }^{7,8}$

\section{METHODS}

A spinal cord lesion refers to any injury to the spinal cord, conus medullaris or cauda equina due to traumatic or non-traumatic insults. This is in accordance with all other International SCI Data Sets. Each variable and each response category within each variable in all International SCI Data Sets have been defined in the best way possible to ensure consistency in the collection and reporting of data and to ensure that the data are collected in a standard format.

It is important that data be collected in a uniform manner to improve patient care and the scientific rigor of research. For this reason, each variable and its accompanying response category reflects the minimal amount of information considered to be essential for capturing the upper extremity status of a person with SCI. In addition, a standardised format has been specified to enable the compilation of data from multiple investigators across different locations. Recommendations for variable names and database structures are available at the ISCoS websites (www.iscos.org.uk) and the National Institute of Neurological Disorders and Stroke (NINDS) the Common Data Elements (CDE) Project website (www.CommonDataElements.ninds.nih.gov). ${ }^{9,10}$ However, various formats and coding schemes may be equally effective and could be used in individual studies or by agreement of the collaborating investigators.

${ }^{1}$ Department for Spinal Cord Injuries, Glostrup Hospital, University of Copenhagen, Copenhagen, Denmark; ${ }^{2}$ The Cleveland FES Center/Case Western Reserve University, Cleveland, OH, USA; ${ }^{3}$ Spinal Cord Injury Center, University of Zurich and University Hospital Balgrist, Zurich, Switzerland; ${ }^{4}$ Department of Hand Surgery, Institute of Clinical Sciences, Sahlgrenska University Hospital and University of Gothenburg, Gothenburg, Sweden; ${ }^{5}$ Rehabilitation Studies Unit, Northern Clinical School, Sydney School of Medicine, University of Sydney, Sydney, New South Wales, Australia; ${ }^{6}$ Jefferson School of Health Professions, Thomas Jefferson University, Philadelphia, PA, USA; ${ }^{7}$ Institute of Biomaterials and Biomedical Engineering, University of Toronto, Toronto, Ontario, Canada; ${ }^{8}$ Division of Neuroscience, University of Alberta, Edmonton, Alberta, Canada; ${ }^{9}$ Burwood Academy of Independent Living, Burwood Hospital, and Department of Orthopaedic Surgery and Musculoskeletal Medicine, University of Otago, Christchurch, New Zealand and ${ }^{10}$ Roessingh Rehabilitation Center, Enschede, The Netherlands

Correspondence: Professor F Biering-Sørensen, Department for Spinal Cord Injuries, Glostrup Hospital, Havnevej 25, Hornbæk DK-3100, Denmark

E-mail: fin.biering-soerensen@regionh.dk

Received 4 February 2014; revised 28 April 2014; accepted 3 May 2014; published online 3 June 2014 
An initial version of the International SCI Upper Extremity Basic Data Set was prepared by a working group comprising the authors. All members of this group have clinical and research experience related to the upper extremity of people with SCI. The Data Set only covers a few essential aspects of upper extremity status and management and was designed to ensure clinicians could easily collect the data in various setting and countries with minimal cost or need for elaborate equipment. It includes the minimal amount of information a clinician would typically collect during a simple and routine evaluation of the upper extremity of a person with tetraplegia following SCI. In order to ensure consistency in the data collection and to facilitate interpretation, detailed information is provided in a syllabus for each specific variable and each response category.

The following steps were followed in the development of this version of the International SCI Upper Extremity Basic Data Set:

(1) The working group of the International SCI Upper Extremity Basic Data Set formulated the data set during extensive e-mail contact among group members. (2) The data set was reviewed by members of the Executive Committee of the International SCI Standards and Data Sets. (3) Comments from the Committee members were discussed among the working group, and appropriate adjustments were made to the Data Set. (4) Members of the ISCoS Executive and Scientific Committees and ASIA Board were also asked to review the data set. (5) Comments from the Committee/Board members were discussed in the working group and a response was made and further adjustments of the Data Set were performed. (6) Relevant and interested scientific and professional (International) organisations and societies (around 40) and individuals were also invited to review the data set. In addition, the Data Set was posted on the ISCoS and ASIA websites for 1 month to allow further comments and suggestions. (7) The working group discussed and responded to comments. Where appropriate, the Data Set was adjusted. (8) Members of the ISCoS Executive and Scientific Committees and ASIA Board members again reviewed and then approved the Data Set. (9) The International SCI Upper Extremity Basic Data Set was then further scrutinised by the team working on the NINDS, CDE Project, in cooperation with the Executive Committee of the International SCI Standards and Data Sets committees. ${ }^{9,10}(10)$ The data set was used to collect information on several training cases to confirm its appropriateness for the clinical setting.

\section{Variables}

The data sheet is included in the Appendix. The data sheet and syllabus are available on the ISCoS website (www.iscos.org.uk).

The training cases demonstrated that the data sheet was easy to fill in and that the variables did not need to be further adjusted.

Listed below are the variables included in the International SCI Upper Extremity Basic Data Set:

Date performed. Data on upper extremity status may be collected at any time following the spinal cord lesion. This means initially after the spinal cord lesion as well as at any given follow-up later. Therefore is the date of data collection imperative to be able to calculate time since the initial spinal cord lesion and to relate the information to other data collected on the same individual at various time points.

Basic hand-upper extremity function. This variable consists of two items: one for the right upper extremity and one for the left upper extremity. Each item describes the hand-arm function as it relates to motor innervation. Handupper extremity function is classified in the following way:

1. No upper extremity function at or below the elbow, that is, no voluntary control of elbow, wrist or hand muscles; no grasping function; severely limited active placing or reaching of the arm.

2. Passive tenodesis hand, that is, passive hand functions with neither voluntary control of extrinsic and intrinsic hand muscles nor ability to actively extend the wrist. Opening and closing of the hand is only possible by supination or pronation of the forearm (passive tenodesis effect), with no active grasping movements of the hand. Bimanual grasping by stabilising objects between two hands or passive tenodesis grasp is effective only in a limited workspace.
3. Active tenodesis hand, that is, no voluntary control of extrinsic and intrinsic hand muscles but active wrist extension allowing for passive movements of fingers dependent on a tenodesis effect. Limited single-handed grasping function in a restricted workspace.

4. Active extrinsic hand, that is, voluntary control of wrist and some extrinsic finger muscles allowing for weak grasping by means of some active opening and closing of the hand with or without tenodesis but with reduced dexterity.

5. Active extrinsic-intrinsic hand, that is, voluntary control of extrinsic and intrinsic hand muscles and the ability to perform different grasp forms (for example, power grip (holding a hammer), precision grip (holding an egg), lateral power pinch (key-grip), precision-pinch (holding a needle)) but with limitations of muscle strength and dexterity.

The description of hand-upper extremity function is based on a pattern of complex muscle innervation and focusses on hand movements. It provides complementary information to measures of activities of daily living (ADL). ${ }^{11,12}$ Although the latter describe impairments of specific functions, they do not reveal the underlying innervation and principal kind of grasp. ${ }^{12,13}$ Also knowledge of the strength of ISNCSCI upper extremity key muscle function does not reveal how the individual is able to use the hand-forearmproximal arm in complex movements. ${ }^{14,15}$ The five levels of hand function integrate the innervation of upper extremity muscles required to perform hand movements (like grasping and holding objects in the hand, manipulation (pro/ supination) and placement) and depend on sufficient voluntary innervation. Therefore, the ability to perform the described hand functions is not only dependent on the innervation per se but also the ability to release movements against potential antagonistic muscles or changes within the fibro-elastic tissues (like increased muscle tone and contractions) counteracting movements. ${ }^{16}$ The combination of these hand function assessments with ADL measures helps distinguish between changes in voluntary control of muscles (such as changes in the neurological level or within myotomes) and changes in skill levels (such as effects of training or non-use). ${ }^{17}$ Therefore, follow-up assessments of these five levels of hand function will help to disclose relevant changes in the way individuals with cervical SCI are able to perform upper extremity and hand movements.

Shoulder function classification. The shoulder function classification is based on observed function of the shoulder and upper extremity. Each side is scored separately according to the following four-point scale:

A No active placing or reaching of the arm.

B Severely limited but able to position hand on a desk, without assistance, but not able to reach to the mouth/head (gravity compromises the movements).

C Limited but able to reach mouth/head with difficulty or altered movements, for example, weak or absent pronation-supination or wrist flexion-extension.

D Full range of movement of shoulder and independent reaching forward and upward.

Scores from the hand-upper extremity function (numerical values from 1 to 5 ) are coupled with scores from this item (letter values from A to D). For example, a person with central cord syndrome or with a high tetraplegia could be scored as $3 \mathrm{~A}$ or $3 \mathrm{~B}$, and a person with less affected shoulder function could be scored as $3 \mathrm{C}$ or $3 \mathrm{D}$. The combination of a numerical value (1-5) and a letter $(A-D)$ defines the whole upper extremity rather than just hand function.

Use of assistive devices. Assistive devices include all equipment used to augment or provide upper extremity/hand function to perform activities. This includes equipment such as universal cuffs, hand splints and orthoses, including spring-loaded types, adaptive devices (built-up utensils, writing, splints, cup holdersand so on), surface functional electrical stimulation (FES) and robotic feeders.

It does not include equipment used for positioning the hand/arm to prevent tightness or contractures (such as static resting hand splints, elbow extension splints), equipment used for therapeutic interventions to train, strengthen or exercise the hand/arm (such as surface therapeutic electrical stimulation, 
passive range of motion machine) and environmental control units, implanted technology and free standing robotic arms.

Clinical practice supports the use of splints, but little evidence about their effectiveness is available in the literature. ${ }^{18}$ Flexor hinge splints ${ }^{19}$ are infrequently used. Suspension and arm support devices are used in individuals with C4-C5 tetraplegia and found to be beneficial; however, evidence about their efficacy is unavailable. ${ }^{20}$ Standardisation of splinting protocols was found to be difficult, ${ }^{21}$ but recommendations about usage of different types of splints are published in textbooks. ${ }^{22,23} \mathrm{~A}$ number of adaptations of writing material, cutlery and ADL equipment (quite often individually made) can be used to enhance usage of impaired upper extremity function. ${ }^{14}$ With surface FES systems, paralysed muscles are stimulated to contraction, which is the function needed, for instance, to provide grasp. The use of FES has been reviewed on numerous occasions. ${ }^{24-26}$ It should be noted that various surface FES systems have very different capabilities and fidelity of the grasp produced.

Robotic-assistive devices such as robotic feeders are used increasingly to improve the independence and quality of life of persons with disabilities. ${ }^{27}$

SCI-related complications affecting upper extremity function like pain, spasms, contractures and oedema. This variable describes complications affecting upper extremity function such as pain, spasms, contractures and oedema. Thus it includes all types of pain such as nociceptive, neuropathic, general or focal pain; spasms whether helpful, harmful, general or focal; minor or major contractures; and oedema.

It does not include concomitant injuries to the extremity at the time of injury, such as brachial plexus injury, amputation, fracture and so on, or selfinflicted injuries to the extremity. The International SCI Pain Basic Data Set provides a more detailed assessment of pain if required.,

Upper extremity/hand reconstructive surgery. This variable documents if reconstructive surgery has been performed specifically for the improvement of arm and/or hand function. It includes any surgical procedures to the arms and/or hands to restore function, that is, soft tissue reconstruction such as tendon transfers, lengthenings and releases; de-rotational osteotomies; and implantation of a functional electrical stimulation system.

It does not include surgical procedures to the arms or hands during initial management of the SCI for repair of concomitant brachial plexus injury or for treatment of concomitant upper extremity fractures, burns or other injuries. It also does not include surgical procedures that may have an effect on the upper extremity but are not performed specifically to the upper extremity to improve function, for example, surgical implant of baclofen pump, and dorsal rhizotomy.

In addition, it does not include surgical procedures to the upper extremity for purposes other than to improve function, for example, surgery for cosmesis; hygiene; positioning; skin grafts for pressure sores, burns and so on; and management of fractures or other injuries.

Reconstructive arm and hand surgery, including surgical implantation of functional electrical stimulation systems and nerve transfers, ${ }^{28-31}$ are sometimes performed after discharge from initial rehabilitation and when patients neurological status is stable. Although these surgeries can include tendon and muscle lengthenings and releases and de-rotational osteotomies, the primary surgical procedure to restore upper extremity function after SCI involves tendon transfers. ${ }^{23,32-37}$ In cases of SCI, tendon transfers are performed when two or more muscles that provide the same function have been preserved; one of the tendons can be transferred to restore distal function without compromise to the original function. As an example, in an individual with a motor level of $\mathrm{C} 5$ with preserved function of the brachialis, biceps and brachioradialis muscles. In this example, the brachioradialis can be transferred distally to restore wrist extension without compromising voluntary elbow flexion. The number of distal movements that can be restored with tendon transfers relies entirely on the number of muscles/tendons available for tendon transfer. $^{38,39}$

Performed upper extremity/hand reconstructive surgery. This variable documents past reconstructive surgery. This includes soft tissue reconstructions, such as tendon transfers for elbow extension, tendon transfers for wrist extension, restoration of pinch and or grasp, tendon/muscle releases and/or lengthenings. It also includes osteotomies with or without rotation and/or arthrodesis of the humerus, radius, ulnar, wrist or fingers/thumb. In addition, this variable includes FES implants and other kinds of related surgery.

Tendon transfer for elbow extension restores or augments active elbow extension. The most common procedures to restore elbow extension in people with SCI are the deltoid-to-triceps transfer and biceps-to-triceps transfer. ${ }^{34-36}$ Tendon transfer for wrist extension restores or augments active wrist extension. This is commonly achieved through a transfer of the brachioradialis to radial wrist extensors. ${ }^{40}$

Tendon transfer for pinch and/or grasp restores or augments active hand function. Various procedures are used. . $^{32,33,41-43}$

Tendon and muscle releases and/or lengthenings, and other surgical soft tissue reconstructions such as the tenodesis procedure, improves arm/hand function. ${ }^{43,44}$

Osteotomies with or without rotation and/or arthrodesis have been performed to position the extremity for function. For example, an internal rotation contracture of the shoulder and/or a supination contracture of the forearm are managed with de-rotational osteotomies to position the arm and forearm for function, respectively. ${ }^{45}$ De-rotational osteotomies are usually done as a precursor to or in combination with tendon transfers. Fusions are performed to stabilise a joint to improve function. The most common joints that are fused are in the thumb. ${ }^{43,46}$

FES systems have been implanted in the upper extremity to provide arm and/or hand movement with voluntarily controlled electrical stimulation. ${ }^{28,47-49}$

Other upper extremity/hand reconstructive surgery procedures include nerve transfer and other surgeries aimed at restoring arm and/or hand function.

\section{DISCUSSION}

The data collected in the International SCI Upper Extremity Basic Data Set will be available in conjunction with the data in the International SCI Core Data Set, which among other items, includes information on date of birth and injury, gender, the cause of SCI, and neurological status. ${ }^{2}$ It is intended that it be used in conjunction with the International SCI Musculoskeletal Basic Data Set. The number of items in the International SCI Upper Extremity Basic Data Set has been kept to a minimum to ensure this basic data set is as useful as possible in a clinical setting. The working group believes that the items included cover the most clinically relevant information about possible upper extremity conditions in individuals with a spinal cord lesion. The working group recognises that information in the International SCI Upper Extremity Basic Data Set could be extended by adding other clinically important information, whenever appropriate.

To facilitate the use of the International SCI Data Sets, this International SCI Upper Extremity Basic Data Set and its accompanying data collection forms (included in the Appendix) have been developed using a similar format as the previous International SCI Basic Data Sets. Additional work and research is now required to validate and translate this data set. We strongly advise that this be done according to the recommendations of the Executive Committee for the International SCI Standards and Data Sets. ${ }^{50}$ The authors invite all those who are interested to participate in this open and ongoing process.

\section{DATA ARCHIVING}

There were no data to deposit.

\section{CONFLICT OF INTEREST}

The authors declare no conflict of interest. 


\section{ACKNOWLEDGEMENTS}

We are thankful for comments and suggestions received from Lawrence Vogel, Susan Charlifue, Marcalee Sipski Alexander, Stephen Kirshblum, Marcel Post, Malka Itzkovich, Amiram Catz, Vanessa Noonan, Douglas Brown and Michael DeVivo.

1 Biering-Sorensen F, Charlifue S, DeVivo M, Noonan V, Post M, Stripling T et al. International Spinal Cord Injury Data Sets. Spinal Cord 2006; 44: 530-534.

2 DeVivo M, Biering-Sørensen F, Charlifue S, Noonan V, Post M, Stripling T et al. International Spinal Cord Injury Core Data Set. Spinal Cord 2006; 44: 535-540.

3 Biering-Sørensen F, Burns AS, Curt A, Harvey LA, Jane Mulcahey M, Nance PW et al. International spinal cord injury musculoskeletal basic data set. Spinal Cord. 2012; 50: 797-802.

4 Widerström-Noga E, Biering-Sørensen F, Bryce T, Cardenas DD, Finnerup NB, Jensen MP et al. The International Spinal Cord Injury Pain Basic Data Set. Spinal Cord 2008; 46: 818-823.

5 Widerström-Noga E, Biering-Sørensen F, Bryce T, Cardenas DD, Finnerup NB, Jensen MP et al. The International Spinal Cord Injury Pain Basic Data Set (version 2.0) 2013, submitted.

6 Kirshblum SC, Burns SP, Biering-Sorensen F, Donovan W, Graves DE, Jha A et al. International standards for neurological classification of spinal cord injury (Revised 2011). J Spinal Cord Med 2011a; 34: 535-546.

7 Catz A, Itzkovich M, Tesio L, Biering-Sorensen F, Weeks C, Laramee MT et al. A multicenter international study on the Spinal Cord Independence Measure, version III: Rasch psychometric validation. Spinal Cord 2007; 45: 275-291.

8 Anderson KD, Acuff ME, Arp BG, Backus D, Chun S, Fisher K et al. United States (US) multi-center study to assess the validity and reliability of the Spinal Cord Independence Measure (SCIM III). Spinal Cord 2011; 49: 880-885.

9 Biering-Sørensen F, Charlifue S, Devivo MJ, Grinnon ST, Kleitman N, Lu Y et al. Incorporation of the International Spinal Cord Injury Data Set elements into the National Institute of Neurological Disorders and Stroke Common Data Elements. Spinal Cord 2010; 49: 60-64

10 Biering-Sørensen F, Charlifue S, DeVivo MJ, Grinnon ST, Kleitman N, Lu Y et al. Using the spinal cord injury common data elements. Top Spinal Cord Inj Rehabil 2012; 18 23-27.

11 Kalsi-Ryan S, Beaton D, Curt A, Duff S, Popovic MR, Rudhe C et al. The Graded Redefined Assessment of Strength Sensibility and Prehension: reliability and validity. J Neurotrauma 2012a; 29: 905-914.

12 Kalsi-Ryan S, Curt A, Verrier MC, Fehlings MG. Development of the Graded Redefined Assessment of Strength, Sensibility and Prehension (GRASSP): reviewing measure ment specific to the upper limb in tetraplegia. J Neurosurg Spine 2012b; 17(1 Suppl), 65-76.

13 Cacho EW, de Oliveira R, Ortolan RL, Varoto R, Cliquet A Jr. Upper limb assessment in tetraplegia: clinical, functional and kinematic correlations. Int J Rehabil Res 2011; 34: 65-72.

14 Kirshblum SC, Waring W, Biering-Sorensen F, Burns SP, Johansen M, Schmidt-Read M et al. Reference for the 2011 revision of the International Standards for Neurological Classification of Spinal Cord Injury. J Spinal Cord Med 2011b; 34: 547-554.

15 Rudhe C, van Hedel HJ. Upper extremity function in persons with tetraplegia: relationships between strength, capacity, and the spinal cord independence measure. Neurorehabil Neural Repair. 2009; 23: 413-421.

16 Steeves JD, Lammertse DP, Kramer JL, Kleitman N, Kalsi-Ryan S, Jones L et al. Outcome measures for acute/subacute cervical sensorimotor complete (AIS-A) spinal cord injury during a phase 2 clinical trial. Top Spinal Cord Inj Rehabil 2012; 18: 1-14.

17 Zariffa J, Kapadia N, Kramer JL, Taylor P, Alizadeh-Meghrazi M, Zivanovic V et al. Effect of a robotic rehabilitation device on upper limb function in a sub-acute cervical spinal cord injury population. IEEE Int Conf Rehabil Robot 2011; 2011: 5975400.

18 Connolly SJ, Mehta S, Foulon BL, Teasell RW, Aubutt JL. Upper limb rehabilitation following spinal cord injury. In: Eng JJ, Teasel RW, Miller MC, Wolfe DL, Townson AF, Hsieh JTC, Noonan V, Mehta S, Sakakibara BM and Boily K (eds). Spinal Cord Injury Rehabilitation Evidence. Version 4.0. Vancouver, BC, Canada. http://www.scireproject. com/rehabilitation-evidence/upper-limb.

19 Nichols PJ, Peach SL, Haworth RJ, Ennis J. The value of flexor hinge hand splints. Prothet Orthot Int 1978; 2: 86-94.

20 Atkins MS, Baumgarten JM, Yasuda YL, Adkins R, Waters RL, Leung P et al. Mobile arm supports: evidence based benefits and criteria for use. J Spinal Cord Med 2008; 31: 388-393.

21 Curtin M. Development of a tetraplegic hand assessment and splinting protocol. Paraplegia 1994; 32: 159-169.

22 Kirshblum SC, Bloomgarden J, Nead C, McClure I, Forrest G, Mitchell J. Rehabilitation after Spinal Cord Injury. In: Kirshblum SC, Campagnolo D. Spinal Cord Medicine. Second Edition. Lippincott/Williams and Wilkins. Philadelphia 2011c, pp 309-340.
23 Mulcahey MJ. Upper limb orthoses for the person with spinal cord injury. In: Hsu JD, Michael JW and Fisk JR (eds). AAOS Atlas of Orthoses and Assistive Devices, 4th edn Elsevier Health Sciences. Mosby Elsevier: Philadelphia, 2008, pp 203-218.

24 Ragnarsson KT. Functional electrical stimulation after spinal cord injury: current use, therapeutic effects and future directions. Spinal Cord 2008; 46: 255-274.

25 Prochazka A. Neuroprosthetics. In: Edelle C and Field-Fote P (eds). Spinal Cord Injury Rehabilitation. FA Davis Company: Philadephia, PA, USA, 2009, pp 87-99.

26 Hitzig SL, Craven BC, Panjwani A, Kapadia N, Giangregorio LM, Richards K et al. Randomized trial of functional electrical stimulation therapy for walking in incomplete spinal cord injury: effects on quality of life and community participation. Top Spinal Cord Inj Rehabil 2013; 19: 245-258.

27 Brose SW, Weber DJ, Salatin BA, Grindle GG, Wang H, Vazquez JJ et al. The role of assistive robotics in the lives of persons with disability. Am J Phys Med Rehabil 2010; 89: 509-521.

28 Peckham PH, Keith MW, Kilgore KL, Grill JH, Wuolle KS, Thrope GB et al. Implanntable Neuroprosthesios Research Group. Efficacy of an implanted neuroprosthesis for restoring hand grasp in tetraplegia: a multi-center study. Arch Phys Med Rehabil 2001; 82: 1380-1388.

29 Keith MW. Neuroprostheses for the upper extremity. Microsurgery 2001; 21: 256-263.

30 Mackinnon SE, Yee A. Ray WZ. Nerve transfers for the restoration of hand function after spinal cord injury. J Neurosurg 2012; 117: 176-185.

31 Fridén J, Gohritz A. Muscle and nerve transfer in tetraplegia. J Neurosurg 2013; 118: 706-707.

32 Keith MW, Peljovich A. Surgical treatments to restore function control in spinal cord injury. Handb Clin Neurol 2012; 109: 167-169.

33 Fridén J, Reinholt C, Turcsánvii I, Gohritz A. A single-stage operation for reconstruction of hand flexion, extension, and intrinsic function in tetraplegia: the alphabet procedure. Tech Hand Up Extrem Surg 2011; 15: 230-235.

34 Kozin S, D'Addesi L, Chafetz RS, Aschworth S, Mulcahey MJ. Biceps-to-triceps transfer for elbow extension in persons with tetraplegia. J Hand Surg Am 2010; 35: 968-975.

35 Leclerq C, Hentz VR, Kozin SH, Mulcahey MJ. Reconstruction of elbow extension. Hand Clinics 2008; 24: 185-201.

36 Mulcahey MJ, Lutz C, Kozin SH, Betz RR. Prospective comparison of biceps to triceps and deltoid to triceps for elbow extension in tetraplegia. J Hand Surg Am 2003; 28 : 964-971.

37 Mulcahey MJ, Weiss A. (eds). Management of the upper extremity in tetraplegia. Hand Clin 2008; 24: 318-488

$38 \mathrm{McD}$ owell $\mathrm{CL}$, Moberg E, House JH. The second international conference on surgical rehabilitation of the upper limb in tetraplegia (quadriplegia). J Hand Surg (Am) 1986; 11A: 604-608.

39 Hentz VR, Curtin CM, Leclercq C. Functional restoration of the upper extremity in tetraplegia. In: VW Lin (ed). Spinal Cord Medicine. Principles and Practice, 2nd edn, Chapter 48. Demos Medical Publishing: New York, NY, USA, 2010, pp 642-658.

40 Fridén J. New concepts $\mathrm{n}$ reconstruction of arm and hand function in tetraplegiabasic science and clinical application. Handchir Mikrochir Plast Chir 2005; 92 : 828-834.

41 Zancolli EA. Midcervical tetraplegia with strong wrist extension: a two stage synergistic reconstruction of the hand. Hand Clin 2002; 18: 481-495.

42 House JH. Reconstruction of the thumb in tetraplegia following spinal cord injury. Clin Orthop Relat Res 1985; 195: 117-128.

43 Waters R, Moore KR, Graboff SR, Paris K. Brachioradilais to flexor pollicis longus tendon transfer for active lateral pinch in the tetraplegia. J Hand Surg Am 1985; 10 : 385-391.

44 Treanor WJ, Monerg E, Buncke HJ. The hyperflexed seemingly useless tetrapelgic hand: a method of surgical amelioration. Paraplegia 1992; 30: 457-466.

45 Coulet B, Boretto JG, Allieu Y, Fattal C, Laffont I, Chammas M. Pronating osteotomy of the radius for forearm supination contracture in high level tetraplegia patients: technques and results. JBJS Br 2010; 92: 828-834.

46 House JH, Comadoll J, Dahl AL. One-stage key pinch and release with thumb carpalmetacarpal fusion in tetraplegia. J Hand Surg Am 1992; 17: 530-538.

47 Kilgore KL, Hoyen HA, Bryden AM, Hart RL, Keith MW, Peckham PH. An implantaed upper extremity neuroprosthesis using myoelectric control. J Hand Surg Am 2008; 33: 539-550.

48 Mulcahey MJ, Betz RR, Smith BT, Weiss AA, Davis SE. Implanted functional electrical stimulation hand system in adolescents with spinal injuries: an evaluation. Arch Phys Med Rehab 1997; 78: 597-607.

49 Gan LS, Ravid E, Kowalczewski JA, Olson JL, Morhart M, Prochazka A. First permanent implant of nerve stimulation leads activated by surface electrodes, enabling hand grasp and release: the stimulus router neuroprosthesis. Neurorehabil Neural Repair 2012; 26: 335-343.

50 Biering-Sørensen F, Alexander MS, Burns S, Charlifue S, Devivo M, Dietz V et al. Recommendations for translation and reliability testing of international spinal cord injury data sets. Spinal Cord 2011; 49: 357-360. 


\section{APPENDIX}

International spinal cord injury upper extremity basic data set form

(Version 1.0)

Date performed: YYYY/MM/DD

Evaluation of the RIGHT and LEFT upper extremity separately:

\begin{tabular}{|l|l|}
\hline Ability to reach and grasp (part of the GRASSP test): & $\begin{array}{l}\text { Shoulder function } \\
\text { classification: }\end{array}$ \\
\hline 1. No upper extremity function at or below the elbow & A. No active placing \\
No voluntary control of elbow, wrist, or hand muscles; no & or reaching of the \\
grasping function; severely limited active placing or reaching & B. Severely limited \\
of the arm. & but able to position \\
2. Passive tenodesis hand & hand on a desk, \\
Passive hand functions with neither voluntary control of & without assistance, \\
extrinsic and intrinsic hand muscles nor ability to actively & but not able to \\
extend the wrist. Opening and closing of the hand is only & reach to the \\
possible by supination or pronation of the forearm (passive & mouth/head (gravity \\
tenodesis effect) with no active grasping movements of hand. & compromises the \\
Bimanual grasping by stabilizing objects between two hands & movements). \\
or passive tenodesis grasp is effective only in a limited & C. Limited but able \\
workspace. & to reach \\
3. Active tenodesis hand & mouth/head, with \\
No voluntary control of extrinsic and intrinsic hand muscles \\
but active wrist extension allowing for passive movements of \\
fingers dependent on a tenodesis effect. Limited single- & difficulty or altered \\
handed grasping function in a restricted workspace. & movements, e.g. \\
4. Active extrinsic hand & weak or absent \\
Voluntary control of wrist and some extrinsic hand muscles & pronation-supination \\
allowing for grasping with or without tenodesis enabling some & or wrist flexion- \\
active opening and closing of the hand but reduced dexterity & D. Full range of \\
and reduction of workspace. & movement (ROM) of \\
5. Active extrinsic-intrinsic hand & shoulder and \\
Voluntary control of extrinsic and intrinsic hand muscles with \\
full workspace and the ability to perform different grasp forms \\
(e.g. power grip, precision grip, lateral power pinch, precision \\
pinch) but potential limitations of muscle strength and & reaching forward \\
dexterity. & and upward. \\
\hline
\end{tabular}

Basic right hand - upper extremity function: ___ (select one number (1-5) and one letter (A-D) from above corresponding to the best description of the hand and upper extremity function)

Basic left hand - upper extremity function: (select one number (1-5) and one letter (A-D) from above corresponding to the best description of the hand and upper extremity function)

INTERNATIONAL SPINAL CORD INJURY UPPER EXTREMITY BASIC DATA SET - 2014.04.28

Use of assistive devices (all equipment like splints, adaptive equipment, surface functional electrical stimulation (FES), etc.) used to enhance upper extremity function:

$\square$ Never or less than monthly

$\square$ Not weekly, but one or more times monthly

Not daily, but one or more times weekly

$\square$ Used daily

Complications affecting upper extremity function like pain, spasms, contractures, and oedema:

$\square$ Minimal - no complications or complications have minimal impact on function

$\square$ Moderate - complications have moderate impact on function

$\square$ Extensive - complications have extensive impact on function

Upper Extremity/Hand Reconstructive Surgery

$\square$ Yes
If Yes, fill in below


Performed Upper Extremity/Hand Reconstructive Surgery

Check all that apply

\begin{tabular}{|c|c|c|c|}
\hline \multirow{10}{*}{$\begin{array}{l}\text { Soft Tissue } \\
\text { Reconstruction }\end{array}$} & Type of surgery & Yes / No / Unknown & $\begin{array}{l}\text { Date of surgery } \\
\text { (yyyy/mm/dd) }\end{array}$ \\
\hline & Tendon transfer for elbow extension (right) & $\square$ Yes $\square$ No $\square$ Unknown & \\
\hline & Tendon transfer for elbow extension (left) & $\square$ Yes $\square$ No $\square$ Unknown & \\
\hline & Tendon transfer for wrist extension (right) & $\square$ Yes $\square$ No $\square$ Unknown & \\
\hline & Tendon transfer for wrist extension (left) & $\square$ Yes $\square$ No $\square$ Unknown & \\
\hline & Restoration of pinch and or grasp (right) & $\square$ Yes $\square$ No $\square$ Unknown & \\
\hline & Restoration of pinch and or grasp (left) & $\square$ Yes $\square$ No $\square$ Unknown & \\
\hline & Tendon/muscle releases or lengthenings (right) & $\square$ Yes $\square$ No $\square$ Unknown & \\
\hline & Tendon/muscle releases or lengthenings (left) & $\square$ Yes $\square$ No $\square$ Unknown & \\
\hline & Other, specify: & $\square$ Yes $\square$ No $\square$ Unknown & \\
\hline \multirow{10}{*}{$\begin{array}{l}\text { Osteotomy } \\
\text { with or without } \\
\text { rotation and or } \\
\text { Arthrodesis }\end{array}$} & Humerus (right) & $\square$ Yes $\square$ No $\square$ Unknown & \\
\hline & Humerus (left) & $\square$ Yes $\square$ No $\square$ Unknown & \\
\hline & Radius (right) & $\square$ Yes $\square$ No $\square$ Unknown & \\
\hline & Radius (left) & $\square$ Yes $\square$ No $\square$ Unknown & \\
\hline & Ulnar (right) & $\square$ Yes $\square$ No $\square$ Unknown & \\
\hline & Ulnar (left) & $\square$ Yes $\square$ No $\square$ Unknown & \\
\hline & Wrist (right) & $\square$ Yes $\square$ No $\square$ Unknown & \\
\hline & Wrist (left) & $\square$ Yes $\square$ No $\square$ Unknown & \\
\hline & Fingers/Thumb (right) & $\square$ Yes $\square$ No $\square$ Unknown & \\
\hline & Fingers/Thumb (left) & $\square$ Yes $\square$ No $\square$ Unknown & \\
\hline $\begin{array}{l}\text { Implantable } \\
\text { FES }\end{array}$ & specify: & $\square$ Yes $\square$ No $\square$ Unknown & \\
\hline Other & specify: & $\square$ Yes $\square$ No $\square$ Unknown & \\
\hline
\end{tabular}

